\title{
Commentary IkB kinase alpha: a link in the chain of the mammary cycle
} Richard Clarkson

\author{
Department of Pathology, University of Cambridge, UK
}

Correspondence: Department of Pathology, University of Cambridge, Tennis Court Road, Cambridge, CB2 1OP, UK. Tel: +44 (0)1223 333541 ; fax: +44 (0)1223 333 346; email: rwec2@mole.bio.ac.uk

\begin{abstract}
The transcription factor NF- $\mathrm{KB}$ exhibits altered activity in some breast cancers but the relevance of this association has not been established. Cao et al.'s elegant study recently published in Cell reveals a NF- $\mathrm{KB}$-dependent signalling pathway responsible for epithelial proliferation in the mouse mammary gland. Could this mechanism, rather than prevention of apoptosis, be responsible for the reported association between NF- $\mathrm{kB}$ and breast cancer? Could the specificity of NF- $\mathrm{kB}$ modulators of the lkB kinase complex determine the fate of epithelial cells at different stages of mammary development?
\end{abstract}

Keywords: apoptosis, IkB kinase, mammary, NF-אB, proliferation

\section{Contribution and relevance to the field}

In vitro studies on NF- $\mathrm{BB}$ signalling have contributed much to our understanding of the multiple effects of NF- $\kappa B$. However, beyond the largely descriptive studies of NF- $\kappa$ B-related phenotypes in animal models, few studies have addressed precisely how NF- $\mathrm{KB}$ mediates its effects in vivo.

The study by $\mathrm{Cao}$ and coworkers [1] provides insight into a NF-кB-dependent signalling pathway with a specific phenotypic outcome in vivo, placing NF- $\kappa B$ as a key regulator of epithelial growth in the developing mammary gland. In the light of previous reports demonstrating a role for NF- $\mathrm{KB}$ in survival of mammary epithelial cells [2,3], the underlying implication of the present study is that the function of NF- $\kappa \mathrm{B}$ in mammary epithelial cells is context dependent and relies on a level of signalling specificity previously not appreciated.

The study involves the use of an inactivatable mutant of $\mathrm{IKK} \alpha$, a component of the heterotetrameric IkB kinase (IKK) complex responsible for activation of NF- $\mathrm{KB}$ by $a$ variety of stimuli, which is thought to convey development- specific signals to NF-кB [4]. Interestingly, this mutant line (unlike IKK $\alpha$ null mice) was normal in nearly all respects (including NF- $\kappa \mathrm{B}$ responses to proinflammatory stimuli) albeit for an abnormal mammary development, similar to that of the receptor activator of NF-кB (RANK)-deficient mice. The morphology of the $\mathrm{IKK} \alpha^{\text {aa/aa }}$ mammary gland was consistent with the expected timing of NF- $\mathrm{BB}$ activation in normal mammary glands of gestating mice [2]. This represents an important tissue specificity in IKK $\alpha$-dependent signalling, which may have implications in other NF$\kappa \mathrm{B}$ settings and in the treatment of breast cancers.

With an upstream IKK $\alpha$ pathway identified, Cao et al. turned to probable downstream NF- $\kappa B$ targets that could be mediating the IKK $\alpha$-dependent phenotype. A previous report of a similar mammary phenotype for cyclin $D_{1}$ knockout mice [5] prompted them to look at cyclin $D_{1}$ expression in their IKK $\alpha$ mutant mice. Confirmation of a marked reduction in cyclin $D_{1}$ expression in these mice led to the 'clinching' experiment: overexpressing a cyclin $D_{1}$ transgene in IKK $\alpha$ mutant mice rescued the IKK phenotype in the mammary gland. This observation confirmed the hypothesis that NF-KB regulated the cell cycle during 
gestation, and firmly established a linear pathway from RANK, via NF- $\kappa B$, to cyclin $D_{1}$.

The observation that NF-KB is responsible for proliferation of mammary epithelial cells during pregnancy is in itself not new. Brantley and colleagues had previously demonstrated that NF-KB positively regulated mammary epithelial proliferation, ductal branching and maintenance of overall mammary structure [6]. However, Cao et al.'s study is significant not only in its identification of the specific signalling pathway responsible for this NF-KB action in the mammary gland, but also in the manner in which it is achieved. The elegant use of crosses between the IKK $\alpha$ mutant and other transgenic lines, previously demonstrated to have mammary phenotypes, combined with tissue-restricted expression of these transgenes, thus demonstrates the increasing power of transgenics in the elucidation of complex signalling pathways.

\section{Future perspectives}

Two intriguing questions arise from the elucidation of this pathway in the mammary gland. How is the specificity for IKK $\alpha$ in the mammary gland achieved, and does the function of NF- $\mathrm{KB}$ change during the course of mammary development? Central to these questions is the identity of the NF- $\kappa B$ isoforms regulated throughout the mammary cycle. Could changes in signalling specificity upstream of $\mathrm{NF}-\mathrm{KB}$ result in a shift in the ratio of activated NF- $\mathrm{KB}$ isoforms with subsequent changes in target gene expression and cellular phenotype? This has not been properly addressed for the complete mammary cycle and warrants further investigation. p52 processing was shown to be affected in IKK $\alpha$ mutant mice in the study of Cao et al. The relatively low level of the p52 isoform compared with the p65 and p50 isoforms, and the fact that there is no mammary phenotype in p52-deficient mice [7,8], however, suggest that this has little or no role prior to lactation.

The relative contributions of IKK $\alpha$ and IKK $\beta$ to the signalling complex vary according to the requirements of the cell. IKK $\beta$ plays a predominant role in immune responses, while IKK $\alpha$ alone appears to be sufficient for at least some developmental systems [9-11]. Cao et al. suggest that the relative contribution of IKK $\alpha$ and IKK $\beta$ to downstream NF-KB activation may occur via alternate upstream kinases, one of which is NIK and the other yet to be defined. This conclusion is supported in an earlier study of human fibroblasts [12].

Perhaps disproportionate activation of components of the IKK complex determines NF-KB responses to specific changes in the local environment during mammary development. NF- $\kappa B$ DNA binding activity is biphasic during mammary development, being downregulated after pregnancy and during lactation, and reactivated at the onset of involution [2]. RANK expression is negligible in involution (Clarkson, unpublished observations, 2002) and is therefore unlikely to be the predominant NF- $\mathrm{KB}$ stimulus at this time. Tumour necrosis factor (TNF) and Fas receptor expression is elevated during involution, and Fas-deficient mice exhibit a mammary involution phenotype [13]. Given that IKK $\alpha^{\text {aa/aa }}$ cells show normal IKK and NF-KB activation in response to TNF $\alpha$, it is intriguing to postulate whether TNF $\alpha$ or Fas, via IKK $\beta$ rather than IKK $\alpha$, may be responsible for the activation of NF-KB in involution.

Could NF-KB thus have distinct roles in pregnancy (proliferation) and involution (survival)? There is increasing evidence in the mammary gland and other tissues that this could indeed be the case. Observation of NF- $\mathrm{KB}$ in a regressing mammary gland in vivo and intervention of $\mathrm{NF}-\mathrm{\kappa B}$ in vitro suggested a role for NF- $\mathrm{\kappa B}$ in mammary epithelial apoptosis $[2,3,14]$. This fits with the paradigm of NF- $\kappa B$ action in other cell types, particularly given the concomitant expression of TNF-receptor family members in mammary epithelial cells during involution.

Since the first conclusive description of NF- $\mathrm{KB}$ acting as a survival factor $[15,16]$ downstream of $T N F \alpha$, literally hundreds of studies have reported the role of NF-KB in apoptotic programmes in a variety of contexts. This may have had the effect of skewing perception of the role of $\mathrm{NF}-\mathrm{KB}$ in developing tissues, including the mammary gland. Indeed, our study of NF- $\mathrm{KB}$ activity in a normal mammary gland concentrated on its role in involution [2]. Studies describing altered NF-KB activities in breast cancers refer to apoptosis as a likely causal mechanism. Cao et al.'s timely contribution to the field has readdressed this balance, highlighting the importance of NF- $\kappa B$ in cell growth during development and its possible relevance to breast cancers.

While evocative, Cao et al.'s suggestion that their observations might explain the association between NF- $\mathrm{KB}$ and breast cancer belies an inconsistency in the available evidence. There have been several reports describing constitutive activity of NF-KB isoforms in human breast cancer cell lines and in primary tumours [17-20]. It is unclear from these studies, however, whether NF- $\mathrm{KB}$ activation or suppression contributes to carcinogenesis, which isoforms are aberrantly regulated or, indeed, whether NF-KB has a causal role rather than simply being a marker of tumour differentiation. While the study of Brantley and coworkers [6] seemed to implicate NF- $\mathrm{KB}$ directly in the phenotypic transformation of mammary epithelial cells in virgin mice, the mechanism underlying this activity remained undefined. Direct regulation of cyclin $D_{1}$ is, however, a promising proposition, as it is overexpressed in $50 \%$ of human primary breast cancers [21]. If NF- $\mathrm{kB}$ is found to be a major contributory factor to human breast cancers then the approach described by Cao et al., to specifically target IKK $\alpha$ signalling and to thereby circum- 
vent proinflammatory pathways, would be an attractive proposition.

An alternative role for NF- $\mathrm{KB}$ in the mammary gland has been proposed by Soler and colleagues [22]. Their studies have implicated NF- $\kappa B$ in the maintenance of the epithelial barrier during remodelling of the mammary gland. This is relevant to all stages of mammary development.

These reports, taken together, support the view that $\mathrm{NF}-\kappa \mathrm{B}$ has different roles to play at different times during mammary development. At this stage, however, we cannot exclude the possibility that NF- $\kappa B$ is exclusively linked to cell-cycle regulation during involution.

\section{Conclusion}

What do Cao et al.'s results mean for the future of NF- $\kappa B$ research? An in vivo study of NF- $\mathrm{KB}$ in mammary involution is clearly required and will no doubt be forthcoming in the near future. Use of conditional transgenics (IKK $\alpha^{\text {aa/aa }}$ and IKK $\beta^{\mathrm{aa} / \mathrm{aa}}$ ) mutants, activated at or around the onset of involution, would help to establish the relative contribution of each of these signalling components in mammary regression. Identification of the NF- $\mathrm{KB}$ isoforms throughout the mammary cycle may also help to determine the phenotypic outcome and alternative upstream pathways responsible for apoptosis and/or proliferation, and may shed light on previous observations in breast cancer cells.

The present study has raised the possibility that two distinct NF- $\kappa B$ signalling pathways exist during mammary gland development. As one of these pathways has been identified, it now remains to be seen whether a similar approach reveals a second pathway later in the developmental cycle.

\section{References}

1. Cao Y, Bonizzi G, Seagroves TN, Greten FR, Johnson R, Schmidt $E V$, Karin M: IKKalpha provides an essential link between RANK signaling and cyclin D1 expression during mammary gland development. Cell 2001, 107:763-775.

2. Clarkson RWE, Heeley J, Chapman R, Aillet F, Hay RT, Wyllie A, Watson C: NF-kB inhibits apoptosis in murine mammary epithelia. J Biol Chem 2000, 275:12737-12742.

3. Geymayer S, Doppler W: Activation of NF-kappaB p50/p65 is regulated in the developing mammary gland and inhibits STAT5-mediated beta-casein gene expression. FASEB J 2000, 14:1159-1170.

4. Rothwarf DM, Karin M: The NF-kappa B activation pathway: a paradigm in information transfer from membrane to nucleus. Sci STKE 1999, 5:RE1.

5. Fantl V, Stamp G, Andrews A, Rosewell I, Dickson C: Mice lacking cyclin D1 are small and show defects in eye and mammary gland development. Genes Dev 1995, 9:2364-2372.

6. Brantley DM, Chen CL, Muraoka RS, Bushdid PB, Bradberry JL, Kittrell F, Medina D, Matrisian LM, Kerr LD, Yull FE: Nuclear factor-kappaB (NF-kappaB) regulates proliferation and branching in mouse mammary epithelium. Mol Biol Cell 2001, 12:1445-1455.

7. Franzoso G, Carlson L, Poljak L, Shores EW, Epstein S, Leonardi A, Grinberg A, Tran T, Scharton-Kersten T, Anver M, Love P, Brown K, Siebenlist U: Mice deficient in nuclear factor (NF)- kappa B/p52 present with defects in humoral responses, germinal center reactions, and splenic microarchitecture. J Exp Med 1998, 187:147-159.

8. Caamano JH, Rizzo CA, Durham SK, Barton DS, Raventos-Suarez C, Snapper CM, Bravo R: Nuclear factor (NF)-kappa B2 (p100/p52) is required for normal splenic microarchitecture and B cell-mediated immune responses. J Exp Med 1998, 187:185-196.

9. Senftleben U, Cao Y, Xiao G, Greten FR, Krahn G, Bonizzi G Chen Y, Hu Y, Fong A, Sun SC, Karin M: Activation by IKKalpha of a second, evolutionary conserved, NF-kappa B signaling pathway. Science 2001, 293:1495-1499.

10. Hu Y, Baud V, Oga T, Kim KI, Yoshida K, Karin M: IKKalpha controls formation of the epidermis independently of NF-kappaB. Nature 2001, 410:710-714.

11. Tanaka M, Fuentes ME, Yamaguchi K, Durnin MH, Dalrymple SA, Hardy KL, Goeddel DV: Embryonic lethality, liver degeneration, and impaired NF-kappa B activation in IKK-beta-deficient mice. Immunity 1999, 10:421-429.

12. Smith C, Andreakos E, Crawley JB, Brennan FM, Feldmann M, Foxwell BM: NF-kappaB-inducing kinase is dispensable for activation of NF-kappaB in inflammatory settings but essential for lymphotoxin beta receptor activation of NF-kappaB in primary human fibroblasts. J Immunol 2001, 167:5895-5903.

13. Song J, Sapi E, Brown W, Nilsen J, Tartaro K, Kacinski BM, Craft J, Naftolin F, Mor G: Roles of Fas and Fas ligand during mammary gland remodeling. J Clin Invest 2000, 106:12091220.

14. Clarkson RWE, Watson CJ: NF-kappaB and apoptosis in mammary epithelial cells. J Mamm Gland Biol Neoplasia 2000, 4:165-175.

15. Beg AA, Baltimore D: An essential role for NF-kappaB in preventing TNF-alpha-induced cell death. Science 1996, 274:782784.

16. Van Antwerp DJ, Martin SJ, Kafri T, Green DR, Verma IM: Suppression of TNF-alpha-induced apoptosis by NF-kappaB. Science 1996, 274:787-789.

17. Dejardin E, Bonizzi G, Bellahcene A, Castronovo V, Merville MP, Bours V: Highly-expressed p100/p52 (NFKB2) sequesters other NF-kappa B-related proteins in the cytoplasm of human breast cancer cells. Oncogene 1995, 11:1835-1841.

18. Nakshatri $H$, BhatNakshatri $P$, Martin DA, Goulet RJ, Sledge GW: Constitutive activation of NF-kappaB during progression of breast cancer to hormone-independent growth. Mol Cell Biol 1997, 17:3629-3639.

19. Sovak MA, Bellas RE, Kim DW, Zanieski GJ, Rogers AE, Traish AM, Sonenshein GE: Aberrant nuclear factor-kappaB/Rel expression and the pathogenesis of breast cancer. J Clin Invest 1997, 100:2952-2960.

20. Cogswell PC, Guttridge DC, Funkhouser WK, Baldwin AS Jr: Selective activation of NF-kappa B subunits in human breast cancer: potential roles for NF-kappa B2/p52 and for Bcl-3. Oncogene 2000, 19:1123-1131.

21. Yu Q, Geng Y, Sicinski P: Specific protection against breast cancers by cyclin D1 ablation. Nature 2001, 411:1017-1021.

22. Soler AP, Marano CW, Bryans M, Miller RD, Garulacan LA, Mauldin SK, Stamato TD, Mullin JM: Activation of NF-kappaB is necessary for the restoration of the barrier function of an epithelium undergoing TNF-alpha-induced apoptosis. Eur $J$ Cell Biol 1999, 78:56-66. 